\title{
STRENGTH PROPERTIES OF LIQUID PENETRATING GEOPOLYMER NO FINES CONCRETE WITH RECYCLED COARSE AGGREGATE
}

\author{
V.S.Ananthakrishnan ${ }^{[1]}$, Dr.V.Sreevidya ${ }^{[2]}$, S.Manoj Prabaakar ${ }^{[3]}$, G.Ezhilarasan ${ }^{[4]}$ \\ ${ }^{1,3,4}$ Post Graduate Students, ${ }^{2}$ Associate Professor, Department of Civil Engineering, \\ Sri Krishna College of Technology, Coimbatore -641 042
}

\begin{abstract}
The aim of this study is to explore the possibility of using abundantly available raw materials such as fly ash from thermal power generation plants subsequent to firing of coal and recycled concrete aggregates obtained from demolished concrete buildings in pervious geopolymer concrete along with chemical activator contents as binding agents without the need to use water. Due to increased demand for housing in urban areas, the existing single storey structures are converted into multi-storey structures to create more housing units. From demolished buildings recycled coarse aggregates are generated. Usage of these aggregates not only reduce the requirement of natural aggregates but also prevent us from finding a place for dumping of these aggregates. In this type of concrete, cement is completely eliminated and in lieu of this, a mixture of fly ash and GGBS (ground granulated furnace slag) are introduced. This inevitably reduce the use of cement fully which is not environmental friendly, for, it emits carbon at the time of manufacturing. With the use of recycled concrete aggregates from demolished buildings, the need for normal coarse aggregates is considerably reduced. During raining, pervious geopolymer concrete can considerably reduce the wastage of run-off water which normally mix with drainage water, thus become unusable. The propotions used are 1:5, 1:6, 1:7, $1 ; 8$.
\end{abstract}

\section{INTRODUCTION}

Universally, Cement is the major raw materials used in all type of concrete. Since production of cement is not environmental friendly, there is imminent need to ascertain a substitute material. In this connection, Fly ash and GGBS, which reduces carbon release, have been considered as substitute materials. Thus, Geopolymer concrete contains chemically activator contents in addition to fly ash and GGBS. With the addition of chemically activator contents, polymerisation takes place through which bonding occurs in Geo-polymer concrete. An added advantage in Geo-polymer concrete is that it can overcome damage, if any, being caused by chemicals.

Consequent to increasing requirement of infrastructure to cater to the needs of increasing industrial development, development of wider rigid pavements for fast movement of finished goods from the place of manufacture to the place of marketing etc., there is inevitably huge requirement of cement and normal aggregates. Fly ash, GGBS and recycled concrete aggregates will, to a greater extent, act as a substitute materials in lieu of cement and normal aggregates for infrastructure development. Due to Government's continuous impetus on infrastructure, the need for building materials is on the increase for laying of new rigid pavements, housing units etc. In urban areas, due to exorbitant requirements, single story structures are demolished to convert them into multi story structures in order to increase housing units. Finding a place for dumping the debris from demolition of existing structures is of great concern. Hence, recycled coarse aggregates from demolished structures can, to a certain extent, replace natural coarse aggregates in concrete. In view of this, blasting of rocky mountain can be considerably reduced which, otherwise, pollute the environment.

Ground granulated blast furnace slag is generated from dowsing melted stoney matter from iron during production. It can also be referred as 'GGBFS' or 'GGBS cement' and the concrete which is made using GGBS is called 'furnace concrete' or 'GGBS concrete'. Fly ash is normally generated in thermal power generation plants subsequent to firing of coal. Chemical activators considered in this geo-polymer concrete are Sodium Silicate and Sodium Hydroxide which acts as binding agents. 
International Journal of Engineering Applied Sciences and Technology, 2020

Vol. 5, Issue 2, ISSN No. 2455-2143, Pages 308-311

Published Online June 2020 in IJEAST (http://www.ijeast.com)

\section{TESTS PERFORMED}

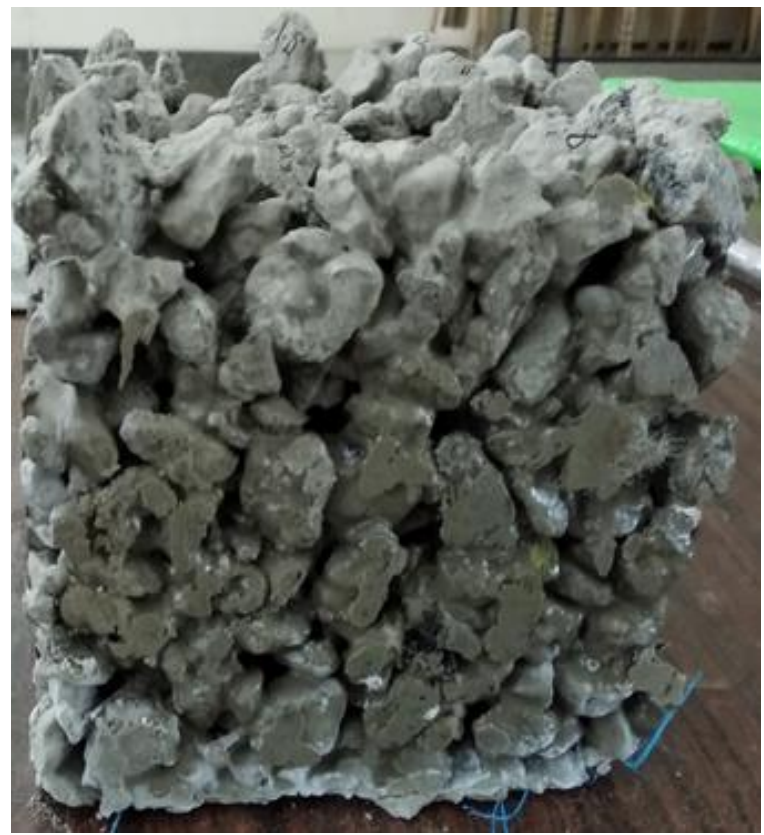

CUBE 1:8 Proportion

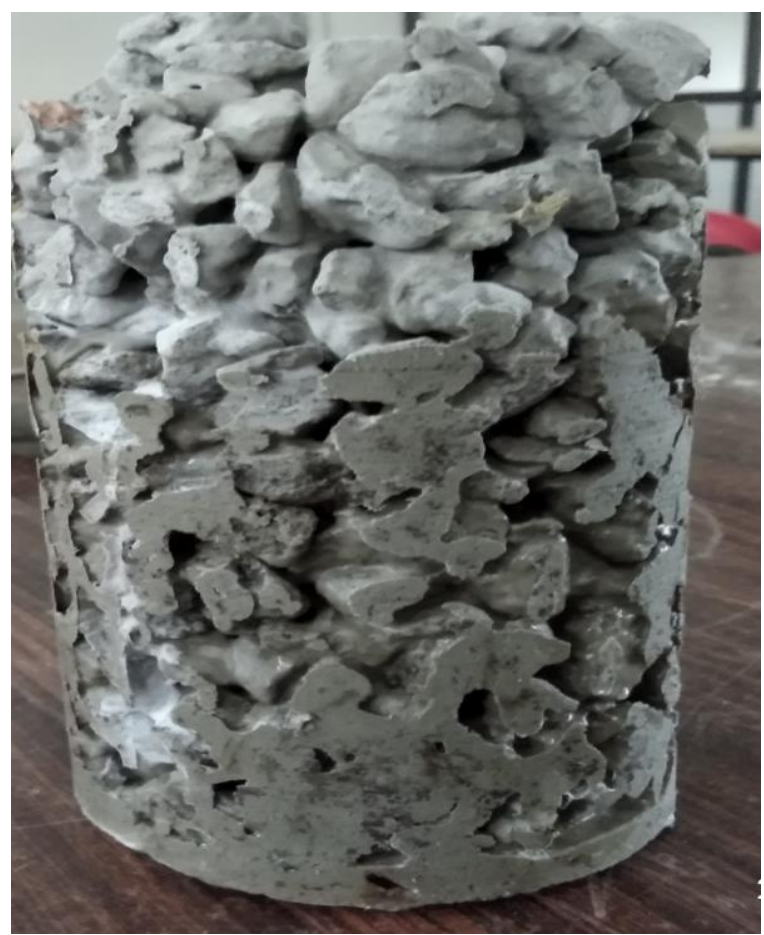

CYLINDER 1:8 Proportion
III. PHYSICAL PROPERTIES

Table 1 Physical Properties of Materials

\begin{tabular}{|l|r|}
\hline Aggregate impact strength & $32.93 \%$ \\
\hline Sieve analysis for M Sand & $2.960 \%$ \\
\hline Sieve Analysis for coarse aggregate & 5.590 \\
\hline Specific Gravity of coarse aggregate & 2.470 \\
\hline $\begin{array}{l}\text { Bulk density of rodded Coarse } \\
\text { aggregate }\end{array}$ & $1.6 \mathrm{~kg} / \mathrm{l}$ \\
\hline Bulk density of loose aggregate & $13.4 \mathrm{~kg} / \mathrm{l}$ \\
\hline
\end{tabular}

\section{PROPORTIONS}

This Experiment is performed by taking Fly ash to coarse aggregate ratio as 1:5, 1:6, 1:7, 1:8. Quantity of fly ash used was $221 \mathrm{~kg}$. The alkaline liquid ratio of $0.35,0.4$ and 0.45 were the mix propotions of pervious Geopolymer Concrete. In this experiment, in order to study the effects of $\mathrm{NH}$ concentration propotions, $10 \mathrm{M}, 12 \mathrm{M}$ and $20 \mathrm{M}$ were considered, however, 12M was used. The dimensions of moulds used for this experiment was $150 \times 150 \times 150 \mathrm{~mm}$ for Cube and $100 \mathrm{~mm} \times 200 \mathrm{~mm}$ for Cylinder. One litre of alkali content weigh $380 \mathrm{~g}$. The casting was done by mixing of Fly ash, GGBs, Sodium silicate, Sodium hydroxide, recycled aggregates and normal aggregates. After casting, the specimens were retained in the mould for 5 days. Once the flyash and chemicals were bonded together due to chemical reaction (Ambient curing), the specimens were demoulded.

Table 2 Mix Proportions

\begin{tabular}{ccc}
\hline Mix No. & Fly ash (kg) & Aggregate \\
\hline PGC 01 & 221 kg & 1105 \\
PGC 02 & 221 kg & 1326 \\
PGC 03 & $221 \mathrm{~kg}$ & 1564 \\
PGC 04 & 221 kg & 1768 \\
\hline
\end{tabular}




\section{TEST RESULTS}

\section{A. Compressive test results}

Concentration of sodium hydroxide solution used was $12 \mathrm{M}$ with ambient curing. The specimen is made of concrete cube with dimension $150 \mathrm{~mm} \times 150 \mathrm{~mm}$ $\mathrm{x} 150 \mathrm{~mm}$. Compressive strength tests were performed when the concrete was 7 days cured. As can be seen from the data provided in Table 3, Figure 1, the test results indicate that with considerable replacement of normal aggregates with recycled concrete aggregates in geo-polymer concrete, 1:8 proportion provides optimum compressive strength.

Table 3 : Compressive strength in MPa

\begin{tabular}{|l|c|l|l|l|}
\hline $\begin{array}{c}\text { Nam } \\
\mathrm{e}\end{array}$ & $\begin{array}{c}\text { Specime } \\
\mathrm{n} 01\end{array}$ & $\begin{array}{c}\text { Specime } \\
\mathrm{n} 02\end{array}$ & $\begin{array}{c}\text { Specime } \\
\mathrm{n} 03\end{array}$ & $\begin{array}{c}\text { Averag } \\
\mathrm{e}\end{array}$ \\
\hline $\begin{array}{l}\text { GPC } \\
01 \\
(1: 5)\end{array}$ & 1.25 & 1.21 & 1.15 & 1.203 \\
\hline $\begin{array}{l}\text { GPC } \\
02 \\
(1: 6)\end{array}$ & 0.67 & 0.69 & 0.71 & 0.69 \\
\hline $\begin{array}{l}\text { GPC } \\
03 \\
(1: 7)\end{array}$ & 2.67 & 2.71 & 2.84 & 2.74 \\
\hline $\begin{array}{l}\text { GPC } \\
04 \\
(1: 8)\end{array}$ & 5.78 & 5.63 & 5.85 & 5.753 \\
\hline
\end{tabular}

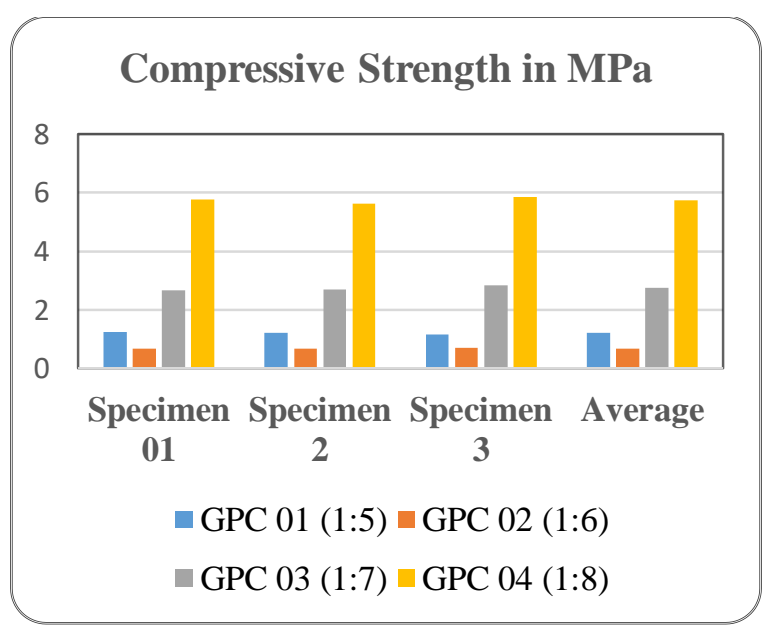

Figure 1 Compressive Strength in MPa

\section{B. Split tensile strength tests}

Split tensile strength of cylinder are increased gradually with increase in aggregate content of each propotions. Four propotions were tested, they are propotions of 1:5, 1:6, 1:7, 1:8. Out of these 4 propotions, 1:8 propotion showed more optimum result.

Table 4: Split Tensile Strength in MPa

\begin{tabular}{|c|c|c|c|c|}
\hline Name & $\begin{array}{c}\text { Specim } \\
\text { en 01 }\end{array}$ & $\begin{array}{c}\text { Specim } \\
\text { en 02 }\end{array}$ & $\begin{array}{c}\text { Specim } \\
\text { en 03 }\end{array}$ & $\begin{array}{c}\text { Avera } \\
\text { ge }\end{array}$ \\
\hline GPC 01 & 0.98 & 0.97 & 0.95 & 0.967 \\
\hline GPC 02 & 1.25 & 1.2 & 1.16 & 1.203 \\
\hline GPC 03 & 0.89 & 0.8 & 0.77 & 0.82 \\
\hline GPC 04 & 1.56 & 1.49 & 1.5 & 1.516 \\
\hline
\end{tabular}

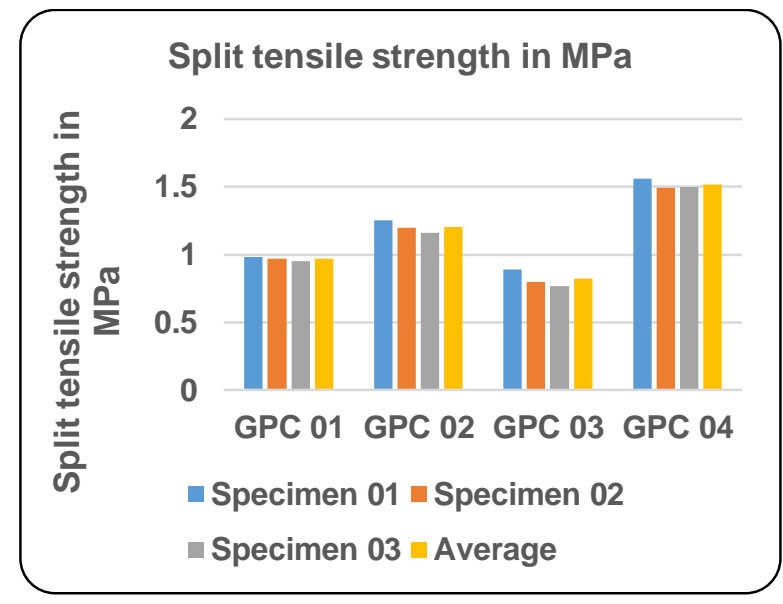

Figure 2 Compressive Strength in MPa

\section{CONCLUSION}

With a view to increasing the use of Fly ash and GGBS as well as recycled concrete aggregates in construction, geo-polymer concrete study has been undertaken. For binding the geo-polymer concrete, in lieu of water, chemical activators are used. The pervious geo-polymer concretes were designed for M30 grade. Upon completion of 7 day curing, tests for cube and cylinder specimens were carried out. Out of four proportions, in 1:8 proportions not only compressive strength and split tensile strength were found to be higher compared to other three proportions but also water permeability was considerably high. Thus, 1:8 proportion cubes and cylinders specimens 
shown maximum results compared to other proportions. During the tests, it has also been observed that compressive strength increases when recycled coarse aggregate content is increased. In addition, infiltration rate is also increased keeping the other materials Fly ash, GGBs etc. without any change in quantities.

\section{Compressive Strength Test}

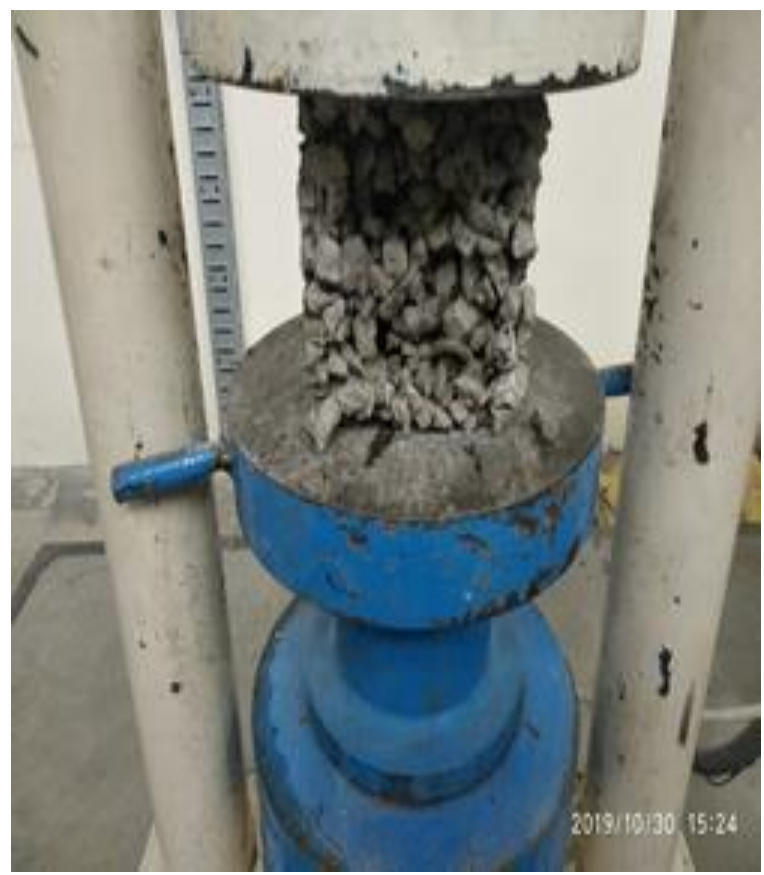

\section{REFERENCES}

1. Pervious High calcium Fly Ash Geopolymer concrete Tawaitchai Tho in, Vanchai Sata, Prinya Chandraprasirt, Chai Jaturapitakkul (2013).

2. Nishant Rana, Abhishek Tiwari Kumar and Alok kumar Srivastava (2016), High performance concrete and its applications in the field of civil engineering.

3. Nik D Oikonomou (2005), Recycled coarse aggregates, cement and concrete composites.

4. JItender Sharma and Sandeep Singla (2014), Study of Recycled concrete Aggregates.
5. V.Vishnu, Dr.G.Arulraj partial replacement of fine aggrega with partial replacement of fine aggregate by m-sand and cement by fly ash, International Journal on Engineering Technology and Sciences, volume 2 issue 2 .

6. Vatsal Patel, Niraj Shah (2013), A survey of High Performance Concrete developments in Civil.

7. Rushikesh Jivani, V.R.Panchal, Jay K Bhasvar(2018), Performance assesement of pervious geopolymer concrete using metakaolin.

8. Anandh Babu Malayali and Ramesh Babu Chokkalingam (2018, development of geopolymer pervious concrete using Ground Granulated Blast furnace slag (GGBS) as raw material and sodium hydroxide and sodium silicate solution as activator.

9. Salaheddin Abdulsalam Arafa, (2016) et al, Optimum Mix for Pervious Geopolymer Concrete (GEOCRETE) Based on Water Permeability and Compressive Strength.

10. Nishant Mishra, (2015), proportion of ground granulated blast furnace slag(GGBS) to be used to attain a good pervious geopolymer concrete.

11. Mohd Mustaffa Al Bakri Abdullah, (2012), the results of a study on the effect of temperature on geopolymers manufactured using pozzolanic materials (fly ash).

12. Olivia Monita, (2011), a study on the strength development, water absorption and water permeability of low calcium fly ash geopolymer concrete.

13. Shaikh Faiz,(2016), mechanical and durability properties of geopolymer concrete containing recycled coarse aggregate (RCA).

14. Faiz Uddin Ahmed Sheikh,( 2016), mechanical and durability properties of geopolymer concrete containing recycled coarse aggregate (RCA). 